УДК 7.032

ББК 85.13

DOI:10.18688/aa155-9-92

Dora Katsonopoulou

\title{
Skopas of Paros and his World: Presentation of a Proceedings volume on Ancient Classical Art
}

The book entitled Skopas of Paros and his World recently published by the Institute for the Archaeology of Paros and the Cyclades, and co-edited with Andrew Stewart of Berkeley University, is the third volume in a series of books published by our Institute under the international title Paros and constitutes the only collective volume ever published on the renowned sculptor of the $4^{\text {th }}$ century BC Classical Greece, Skopas of Paros (Ill. 142). The first volume of the Institute's series entitled Paria Lithos, Parian Quarries, Marble and Workshops of Sculpture published in 2000 and reprinted in 2010, contains 63 papers by leading experts on the famous Parian marble, the location and long history of the Parian quarries from antiquity until the $19^{\text {th }}$ century AD and the accomplishments of the Parian workshops of sculpture, particularly between the $6^{\text {th }}$ and the $4^{\text {th }}$ centuries BC. The second volume of the series entitled Archilochos and his Age published in 2008, includes 30 scholarly papers dealing with the poetry and personality of the reputed Parian poet of the $7^{\text {th }}$ century BC, Archilochos, and the history and archaeology of Paros, Thasos and the Cyclades in his time.

The third volume on Skopas of Paros and his World, which I have the pleasure to present here, is a collection of 34 scholarly papers announced during the Third International Conference on the Archaeology of Paros and the Cyclades held in Paroikia, the contemporary capital of Paros, on June 11-14, 2010. More than thirty colleagues from all over the world came to Paros and presented the results of their scientific work and studies on Skopas and his oeuvre. During the Conference, we organized visits to the local Archaeological Museum and its collection of unique original marble sculptures and to important archaeological sites of Paros including recently discovered sculpture workshops in Paroikia, of particular relevance to the theme of the Conference. Our visits also included the site of the famous ancient marble quarries of Paros, and especially the well known underground stoa of the Nymphs named after the carved relief above its entrance dedicated to the Nymphs, and dating to ca. mid $-4^{\text {th }}$ century BC. Here we had a unique opportunity to attend an instructive outdoors seminar on sculpture by a local sculptor who keeping with ancient tradition of the island creates his own sculptures of marble from fragments collected from the quarries area, using tools of an ancient artisan.

The volume is divided into four parts. Part I, entitled Skopas of Paros and Earlier Parian Sculpture, includes 8 studies on the sculptor's personality and work, and his relationship to the island and its previous sculptural output. It begins with a paper by Andrew Stewart entitled Desperately seeking Skopas presenting an overview of Skopas and his work on the basis of the literary and recent archaeological evidence relevant to the investigation of his artistic personality, and including discussion of some individual works of the artist offering new or 
overlooked evidence for their date and attribution as well as the presentation of a new reconstruction of the interior of Skopas' temple at Tegea based on recent work from the site. In the second paper entitled Skopas and Paros (II) by Dora Katsonopoulou, a link between the particular art of Skopas and Parian sculpture workshops in the period just preceding his time is proposed - in continuing and strengthening an earlier thesis of the author published with her article entitled Skopas and Paros at the NumAntcl in 2004 - via the presentation of recent finds of sculpture from excavations in Paros and an analysis of the influence of the island's cultural environment and heritage upon the sculptor's personality. Specific elements that characterize Skopas' work as architect and sculptor are considered in Skopas of Paros and Damophon of Messene by Petros Themelis, as a standard in relation to output of the later Messenian artist Damophon who created numerous divine and heroic statues and was probably the architect of the temple of Despoina at Lykosoura and the sanctuaries of Zeus Soter and Asklepios at Messene in the Peloponnese.

The historical context of the era in which Skopas executed his great artistic projects at the Artemision at Ephesos, the Maussoleion at Halikarnassos, the temple of Athena Alea at Tegea, and the triad of Eros, Pothos and Himeros for the temple of Aphrodite at Megara, is examined in Skopas of Paros and the Fourth century BC by David Tandy. The products of Parian sculpture workshops dating before Skopas' time as early as the beginnings of the $7^{\text {th }}$ century BC are considered in the paper Sculpture in Paros before Skopas by Foteini Zafeiropoulou, via presentation of significant finds mainly of the $6^{\text {th }}$ and $5^{\text {th }}$ centuries BC from the last few decades of excavation on the island. Further, the archaic temple of Apollo at Despotiko on Antiparos - the island in the major geographical area of Paros - established in the late $6^{\text {th }}$ century BC, and its important caché of archaic kouroi and korai are discussed in The archaic sanctuary of Apollo and the Parian workshops of sculpture before Skopas by its excavator Yannos Kouragios. As a case study of the work of itinerant Parian artists before Skopas, the sculptor Aristion and his famous statue of Phrasikleia and relative evidence on their Parian artistic origin are the subject of the paper entitled An itinerant Parian before Skopas: Aristion, Phrasikleia and the problem of regional styles by Vasiliki Barlou. Finally, the sculpture workshops discovered in recent years in Paroikia, the modern capital of Paros, and their output from Skopas' time until the Roman period are presented and analyzed in the paper Ancient marble workshops on Paros: From the time of Skopas to the Roman period by Sofia Detoratou.

Part II of the volume, entitled Skopas the Architect, contains 9 papers on the artist's reported architectural projects. This part starts from Skopas' Parian roots and the construction of the Prytaneion and the temple of Hestia in the city of Paros, discussed and compared with other architectural projects undertaken by the Parian artist such as the Artemision at Ephesos, the Maussoleion at Halikarnassos and the temple of Athena Alea at Tegea in the paper entitled The sanctuary of Hestia on Paros and its possible links with Skopas by Aenne Ohnesorg. In his paper Skopas from Paros: Peloponnesian architect at Tegea, Erik Østby presents recent data, including the question of Cycladic elements, concerning Skopas' most prominent architectural creation, the temple of Athena Alea at Tegea in Arkadia. The iconography, interpretation, and restoration of the pedimental compositions and akroteria of the Tegean temple is the subject of the work The pedimental compositions and the akroteria of the Skopaic temple of Athena Alea at Tegea by Georgios Mostratos who also offers an interpretative approach to the symbolisms 
of the compositions. The rôle of the Skopaic temple at Tegea as a model for others in the Peloponnese, such as those of Zeus at Nemea and of Ephesian Artemis at Alea in upper Argolis, is evaluated by Dimitris Kousoulas in his paper The architectural work of Skopas' school: problems of Peloponnesian art.

Consequently, in the article entitled Skopas and the altar in the sanctuary of Athena Alea at Tegea, the renowned Parian artist is proposed by Iphigeneia Leventi as the architect-sculptor of another monument, the altar in the Tegean sanctuary, on the basis of both his prior experience with the sculptural embellishment of the Maussolleion at Halikarnassos and the Hecatomnid rulers' association with the sanctuary of Athena Alea. The role of Skopas as an architect, master sculptor, and cult statue maker at Samothrace is critically reviewed in Skopas and the sanctuary of the great gods on Samothrace by Bonna Wescoat via a reevaluation of the plan and elevation of the Hall of Choral Dancers and its links with northern Greek and Macedonian architecture. Finally, Skopas' architectural work in Asia Minor and mainland Greece is examined by Poul Pedersen in his paper entitled Skopas the architect: Architectural relations between the $4^{\text {th }}$ century BC Ionian Renaissance and mainland Greece, looking for possible interactions with local traditions and tracing some elements of the east Greek architecture in the Tegean altar. Particular attention to exploring Skopas' responsibility for the altar of the late Classical Artemision at Ephesos is drawn by Anton Bammer in his work entitled The Artemision at the time of Skopas: Was Skopas the architect of the altar? - actually proposing that the Parian artist was in all probability the architect of the Ephesian altar. Lastly, the friezes of the Maussolleion at Halikarnassos and especially one slab including the representation of a twisted Amazon are discussed by Stephan Schmid in his paper entitled The twisted Amazon: A small mistake with a big effect at the Maussolleion of Halikarnassos.

Part III of the volume, entitled Skopas the Sculptor, includes 12 papers on his art and the statues he created for various cities of the ancient world in the course of his long career. To introduce Part III, which is devoted to Skopas' work as a sculptor and cult-statue maker, the only known copy of one of the Parian artist's most famous works, the Dresden Maenad, is revisited and a new reconstruction of its unusual twisting pose is proposed by Beryl BarrSharrar showing that the Dresden statue may be a quite accurate copy of Skopas' original masterpiece, in her article The Dresden Maenad and Skopas of Paros. Regarding the same statue, an interpretation of its movement in a Dionysiac context is advanced in relation to earlier and later works in this vein including the bronze Satyr from Mazara del Vallo by Christina Wolf in her work The Maenad in Dresden and the conception of movement in the $4^{\text {th }}$ century BC. The evocative description of Skopas' Maenad by Kallistratos as an affecting reaction to the writer's autopsy of the statue (Statuarum descriptiones 2) is further discussed as an ekphrasis comparable to that of the shield of Achilles in Book 18 of the Iliad by Yiannis Petropoulos in his article Ekphrasis as oral performance: Kallistratos' rhetoricising description of Skopas' statue of a Maenad. Alternatively, the late Wilfred Geominy in his paper entitled Looking for a new Skopaic Maenad proposes the so-called Berlin Dancer, a figure he considers as corresponding well with the style of a $4^{\text {th }}$ century sculpture, as actually representing this masterpiece of Skopas instead of the Dresden Maenad.

Next, the famous group of Aphrodite and Pothos created for the sanctuary of the Great Gods at Samothrace is discussed in relation to the extant literary and archaeological evidence 
by Clemente Marconi in his work Skopas in Samothrace; on the other hand, its statue of Aphrodite welcomed here by Pothos and Phaethon is sought in the naked Anadyomene type of the goddess emerging from the sea and preserved in Roman copies by Angelos Delivorrias in his paper Skopadika IV. Aphrodite, Pothos and Phaethon in the sanctuary of Samothrace: Re-evaluating the data. Ersilia Lopes in her work entitled Longing for Pothos at Samothrace puts forward a discussion of Pothos itself in the light of new information gained from literary and archaeological evidence. Moreover, regarding the statue of Pothos two hitherto unrecognized intaglio versions of it in the Thorvaldsen Collection are presented by Marie Kluge in her article entitled A possible representation of Pothos on two gems from the Thorvaldsens $M u$ seum. With regard to Skopas' works reported in Rome, the statue of Eros Thunderbolt-Bearer erected in the late Classical period probably in Athens and later taken to Rome is examined, and its attribution to Skopas is revived by Antonio Corso in his paper Cupido fulmen tenens, and all the sculptor's statues in Rome listed by Pliny are analyzed, shedding new light on his influence upon Roman art and culture, by Giuliana Calcani with her paper entitled Searching for Skopas in Rome. Next, Skopas' work in Knidos of Asia Minor is investigated by Christine Özgan in her paper Skopas in Knidos on the basis of fourth-century marbles from the site that clearly demonstrate the impact of his style. Lastly, Skopas' presence and that of his workshop during the construction of the temple of Artemis at Ephesos is examined via certain sculptures from the altar and the temple exhibiting Skopaic features by Ulrike Muss in her article entitled Sculptures from the Artemision at Ephesos.

Finally, Part IV, entitled The Impact of Skopas' Work, contains 5 papers on the influence that the sculptor's art exerted during the ancient world period. Part IV starts with regions of mainland Greece, such as the Apollo sanctuary at Delphi, where a revival of Parian marble and workmanship during the $4^{\text {th }}$ century BC has been documented by new discoveries presented by a curator at the Museum of Delphi Elena Partida in her work Parian creators and $a$ new find of the age of Skopas at Delphi. Also, further north on Thasos, a Parian colony, on the basis of unpublished marble sculpture in Skopas' manner discovered at Herakleion of Thasos and presented here for the first time since its discovery in the first decades of the $20^{\text {th }}$ century, the influence of the sculptor's art is discussed by Dora Katsonopoulou and Elena Korka in their paper entitled A female marble head of Skopaic influence (?) from Thasos. Sculptures (portraits and others) at Alexandria exhibiting Skopaic stylistic features are analyzed, and the channels through which knowledge of his art infiltrated the city's historical and cultural fabric are investigated by Elena Ghisellini in her work Skopas' echoes in Alexandrian sculpture. The influence of Skopas and his workshop in Egypt and Macedonia is studied by Gianfranco Adornato in the paper entitled Drawings after ancient statuary and workshop practice: Detecting Skopaic influence through drawings on the Artemidoros Papyrus of the $1^{\text {st }}$ century AD and finds from the Royal Tomb II at Vergina. Finally, collections of ancient sculpture of the first half of the $4^{\text {th }}$ century BC and the Hellenistic period from the north Pontic region, where the influence of Skopas is particularly evident, are presented and analyzed by Anna Trofimova in her work entitled The influence of Skopas' style on ancient sculpture from the North Pontic area.

Having offered above a brief summary of all four parts and their contents of 34 scholarly contributions included in our Proceedings volume entitled Skopas of Paros and his World, I would like to conclude with the observation that Skopas' dual personality as renowned sculp- 
tor and architect, and his prolific oeuvre in both areas of sculpture and architecture created in many different parts of the ancient world where he travelled and worked, from Attica, Boeotia, and the Peloponnese, to Samothrace, the Propontis, to Ionia and Karia, as reviewed and discussed on the basis of new literary and archaeological evidence in the scholarly papers of the volume, have certainly become more enlightened to the benefit of scholarship worldwide.

Title. Skopas of Paros and his World: Presentation of a Proceedings volume on Ancient Classical Art.

Author. Dora Katsonopoulou - Full professor, President. The Institute for the Archaeology of Paros and the Cyclades, Paroikia, 84400 Paros, Greece. paros.iapk@gmail.com

Abstract. The paper briefly discusses the contents of a recent publication of the Institute for the Archaeology of Paros and the Cyclades dedicated to one of the most renowned sculptors of Classical Greece, Skopas from the island of Paros. The volume entitled Skopas of Paros and his World, edited by the Institute's President Dora Katsonopoulou and Andrew Stewart of Berkeley University, is the third in a series of books published by the Institute under the international title Paros, and constitutes the only collective volume ever published about this famous Greek sculptor. The 34 scholarly papers of the volume are arranged into four parts as follows. Part I entitled Skopas of Paros and Earlier Parian Sculpture, includes 8 studies on the sculptor's personality and work, and his relationship to the island and its previous sculptural output. Part II entitled Skopas the Architect, contains 9 papers on the artist's architectural projects and Part III entitled Skopas the Sculptor, includes 12 papers on his art and the statues he created for various cities of the ancient world in the course of his long career. Finally, Part IV entitled The Impact of Skopas' Work, contains 5 papers on the influence that the sculptor's art exerted over the ancient world.

Keywords: Skopas of Paros; sculpture; architecture; the Institute for the Archaeology of Paros and the Cyclades.

Название статьи. Скопас с острова Парос. Сборник статей по истории античного искусства.

Сведения об авторе. Кацонопулу Дора - профессор, президент Института археологии Пароса и Кикладских островов. Парикия, Парос, Греция, 84400.paros.iapk@gmail.com

Аннотация. В статье в сжатом виде излагается содержание недавно выпущенного Институтом археологии Пароса и Кикладских островов сборника статей, посвященных исследованию личности и творчества одного из самых выдающихся скульпторов классической Греции - Скопаса, родившегося на острове Парос. Сборник, названный «Мир Скопаса с острова Парос», вышел под редакцией президента Института, автора настоящей статьи, Д. Кацонопулу и профессора Университета в Бэркли (США) Э. Стюарта. Это третий выпуск в серии издаваемых Институтом книг под общим названием «Парос» и единственная в своем роде подборка материалов о Скопасе, в состав которой вошли тридцать четыре статьи, сгруппированные в четыре раздела. Первый из них, названный «Скопас с острова Парос и ранняя паросская скульптура», включает восемь работ, авторы которых исследуют материалы о личности и творчестве самого скульптора во взаимосвязи со скульптурным наследием острова, развивавшимся в предшествующее его жизни время. Раздел «Скопас архитектор» состоит из девяти статей, посвященных архитектурным проектам мастера, а в третий — «Скопас скульптор» - вошли двенадцать работ о статуях, созданных им для разных городов на протяжении долгой творческой жизни. Последний раздел называется «Творческое влияние Скопаса» и состоит из пяти статей, в которых рассмотрено влияние, оказанное творчеством Скопаса на художественную жизнь античной ойкумены.

Ключевые слова: Скопас; остров Парос; скульптура; архитектура; Институт археологии Пароса и Кикладских островов. 